units of procaine penicillin daily for 10 days should be adequate. It can be confidently anticipated that the child will not be syphilitic.

The fact that the blood Wassermann reaction remains positive in the mother does not necessarily mean that her treatment has been inadequate, especially if her infection is of long standing. She certainly requires full investigation, including tests of the cerebrospinal fluid if these have not been done, but further investigation other than clinical examination might reasonably be postponed until after delivery. The possibility of reinfection should not be overlooked and the husband should be examined and tested

\section{Chromium Dust}

Q.-What are the ill effects on health of inhaling fine, chromium-containing dust from polishing steel plates by means of abrasive belts (emery and chalk powder)? What can be done to avoid ill effects if any?

A.--The chromium in the dust must be in a very fine state of subdivision. The concentration and the valency of the chromium present are not stated. If the chromium is in hexavalent form, chrome ulceration of the nasal septum might occur. Local exhaust ventilation to trap the dust at source would be the best method of avoiding ill effects. As an alternative, some form of mask should be worn, and, since the dust is very fine, a micro-filter or similar mask would be the most suitable.

Trichlorethylene and Adrenaline

Q. - It is stated that trichlorethylene must not be used with adrenaline. Is it safe to use lignocaine with adrenaline for delivery after giving trichlorethylene in the second stage of labour? If not, would you advise using lignocaine without adrenaline?

A.- - It is true that inhalation of trichlorethylene under certain circumstances has apparently stopped the heart though no case has been reported in midwifery while a standard trichlorethylene inhaler for analgesia was being used. There is little danger in using adrenaline in appropriately dilute solution (at least as regards the action on the heart) with a perineal or pudendal nerve block if trichlorethylene has previously been used for analgesia, but it is certainly advisable not to use it if trichlorethylene analgesia is to be used at the same time. There is, however, no need to use adrenaline, since the "safe" dose, 40-50 $\mathrm{ml}$., of $0.5 \%$ plain lignocaine is adequate for the nerve blocks cited.

REFERENCE

1 Norris, IV., and Stuart, P., Brit. med. J., 1957, 1, 860.

First Cousins Once Removed

Q. - A woman, aged 23, intends to marry her father's maternal first cousin, aged 41 . There is no particular familial disease recalled on either side. Are there any genetic hazards?

A.- The relationship here is first cousin once removed The risk to children would be about one half of the risk to the children of first cousins. First cousins have, on the average, 1 in 8 of their genes in common, and first cousins once removed 1 in 16 .

Estimates of the risks to children of first cousins are now available from Sweden, France, Japan, and the U.S.A. In general the risk of illness in infancy or childhood is increased by rather more than $100 \%$. For first cousins once removed the risks would be an increase of 50 to $75 \%$. But the risk would still be small.

There is no reason to dissuade the couple, apart from telling them of the small increase in the risk of illness and malformation. Further, they should be told that if they do lose a child they should not assume that it is because of their relationship, but that they should get advice on this.

\section{Renal Threshold for Glucose in Pregnancy}

Q.-Is a low renal threshold for glucose more common in pregnant than in other women? Is it of any significance when found in pregnant women?

A. - There is good evidence that the renal threshold for glucose is lowered during pregnancy. The amount of glucose lost in the urine is small, and in most cases the low renal threshold is of little significance. In pregnant diabetics it complicates the control of the diabetes; frequent estimations of the blood sugar may be needed and there is increased susceptibility to diabetic ketosis. An interesting study of glycosuria and lactosuria in pregnancy was presented by Flynn, Harper, and de Mayo. ${ }^{1}$

$$
\text { REFERENCE }
$$

Flynn. F. V.. Harper, C., and de Mayo, P., Lancet, 1953, 2, 698

\section{Delayed Reaction to Penicillin}

Q. $-A$ child had a course of intramuscular penicillin which finished on January 27, and on March 13 he developed a generalized urticarial rash. Could it have been a delayed reaction to penicillin?

A. - It is possible, but unlikely, that the urticarial rash was due to penicillin, since the penicillin injections finished just over six weeks before the onset of the rash. It is the general experience that a delayed reaction to penicillin usually occurs 7 to 12 days after the sensitizing dose. Hansel $^{1}$ records that it may be delayed as long as three weeks, and Feinberg et al. ${ }^{2}$ say as long as four weeks, but Brown ${ }^{3}$ states that in rare cases the urticaria did not appear until 60 days after penicillin treatment had ceased.

REFERENCES

Hansel, F. K., Clinical Allergy, 1953, p. 98. Henry Kimpton, London. Feinberg. S. M., and Feinberg, A. R., J. Amer. med. Ass., 1956, 160. 778.

Brown. E. A., in Progress in Allergy, III, 1952, p. 509. S. Karger, Basel.

Acknowledgments.-The portrait photograph of H.R.H. the Prince Philip, Duke of Edinburgh, is by Baron. The photographs in the Supplement are by the Keystone Press Agency.

Corrections.-We much regret that in our report of the proceedings of the Section of Tropical Medicine at the B.M.A. Annual Meeting in Edinburgh we wrongly reported Professor B. G. MAEgRaITH as stating, "Whether it was worth treating benign tertian malaria had to be decided on individual merits" (Journal, September 26, p. 570). What we should have said was, "Whether it was worth trying to produce radical cure of benign tertian malaria had to be decided on individual merits."

It is the British Diabetic Association which is to form a medical section in this country, and not the International Diabetics Federation as stated in the issue of October 10, p. 680.

Collected Articles from the "British Medical Journal "

The following books are available through booksellers or from the Publishing Manager, B.M.A. House. Prices, which include postage, are now the same for both inland and overseas.

Energencies in General Practice (26s. 9d.).

Refresher Course for General Practitioners, Volumes 2 and 3 (26s. 9d. each)

Clinical Pathology in General Practice (22s. 3d.).

Any Questions?, Volumes 2 and 3 (8s. 3d. each).

All communications with regard to editorial business should be addressed to THE EDITOR, BRITISH MEDICAL JOURNAL B.M.A. HOUSE, TAVISTOCK SOUARE, LONDON, W.C.1. TELEPHONE: EUSSTON 4499. TELEGRAMS Aitiology, Westcent, London. ORIGINAL ARTICLES AND LETTERS forwarded for publication are understood to be offered to the Britis/t Medical Journal alone unless the contrary be stated.

Authors desiring REPRINTS should communicate with the Publishing Manager, B.M.A. House, Tavistock Square, W.C.1, on receipt of proofs. DVERTISEMENTS should be addressed to the Advertisement Director. B.M.A. House, Tavistock Squarc, London, W.C.1 (hours 9 a.m. to 5 p.m.). TELEPHONE: EUSTON 4499. TELEGRAMS: Britmedads, Westcent, London. MEMBERS' SUBSCRIPTIONS should be sent to the SECRETARY of the Association. TelephONE: EUSTON 4499. Telegrams: Medisecta. Westcent, London.

B.M.A. Scortish OFFICE: 7, Drumsheugh Gardens. Edinburgh. 